\title{
PENGARUH LAMA PERENDAMAN AIR KELAPA TERHADAP PERTUMBUHAN DAN HASIL TANAMAN BAWANG MERAH (Allium ascalonicum. L) PADA BERBAGAI MACAM MEDIA
}

\author{
Fendi Ramadhani ${ }^{1)}$, Tri Kurniastuti ${ }^{2)}$, Palupi Puspitorini ${ }^{2)}$ \\ ${ }^{1)}$ Mahasiswa Fakultas Pertanian Universitas Islam Balitar \\ ${ }^{2)}$ Dosen Fakultas Pertanian Universitas Islam Balitar \\ Email : fendiramadhani847@gmail.com
}

\begin{abstract}
Conducted using factorial randomized block design (RBD) with 2 factors, the first factor was immersion in coconut water $(\mathrm{k})$ which consisted of 3 levels namely immersion for 1 hour (k1) soaking for 2 hours $(\mathrm{k} 2)$ soaking for 3 hours $(\mathrm{k} 3)$. The second factor is various media (m) consisting of 3 levels: soil 1: fertilizer 1: husk ash 1 (m1), soil 2: fertilizer 1: husk ash 1 (m2), soil 1: fertilizer 2: husk ash 1 ( m3) The variables observed included plant height, number of shoots, number of leaves, weight of tuber stover, wet weight of tubers, dry weight of tubers. Data were analyzed using analysis of variance (ANOVA) level of 5\% and further testing with Duncan's Multiple Range Test (DMRT). There is no real interaction between coconut water immersion and various planting media on the growth and yield of shallots. The treatment of coconut water immersion (k) significantly affected the height of shallot plants at the age of 14 days and 21 days, and affected the number of shoots and leaves at all ages of observation. The treatment of various planting media showed a significant difference at the age of 14 days to 21 days. The treatment of various planting media had a significant effect on the weight of stover and the wet weight of onion tubers with the highest yield (m1) of $122.03 \mathrm{gr}$, while in the wet weight the highest yield was on media (m1) with a yield of 80.51 gr.
\end{abstract}

Keywords: Coconut Water, Red Onion, Planting Media.

\section{Pendahuluan}

Bawang merah (Allium ascalonicum $\mathrm{L}$ ) merupakan salah satu komoditas tanaman hortikultura yang banyak dikonsumsi manusia sebagai bumbu masakan. Selain sebagai campuran bumbu masak, bawang merah juga dijual dalam bentuk olahan makanan, bumbu masak, dan bahan obat. Sebagai komoditas hortikultura yang banyak dikonsumsi masyarakat, potensi pengembangan bawang merah masih terbuka lebar tidak saja untuk kebutuhan dalam negeri tetapi juga luar negeri (Suriani, 2012).

Untuk meningkatkan produksi bawang merah dapat dilakukan dengan teknik budidaya yang maksimal, salah satu usaha yang dapat dilakukan adalah dengan pemberiaan Zat Pengatur Tumbuh (ZPT) untuk perendaman bibit. Zat pengatur tumbuh adalah senyawa organik yang dalam konsentrasi rendah mampu mendorong, menghambat atau secara kualitatif mengubah pertumbuhan dan perkembangan tanaman(Prihatmanti, 2002). ). Zat pengatur tumbuh dapat dibagi menjadi beberapa golongan yaitu auksin, 
sitokinin, giberelin, dan inhibitor. Salah satu ZPT yang dapat digunakan adalah ZPT alami yang berasal dari Air kelapa.Menurut Rajiman (2014) air kelapa mengandung auksin, sitokinin, asam amino, vitamin, dan mineral komposisi ini akan berpengaruh terhadap pertumbuhan dan hasil bawang merah. Air kelapa merupakan salah satu bahan alami yang mengandung hormon sitokinin $5,8 \mathrm{mg} / \mathrm{l}$, auksin $0,07 \mathrm{mg} / \mathrm{l}$. (Yong J,W,H et al.,2009).

Selain itu upaya untuk meningkatkan produksi tanaman bawang merah dapat dengan berbudidaya misalnya pada media tanam.Media tanam berpengaruh pada pertumbuhan tanaman karena media tanam yang menyediakan nutrisi bagi tanaman. Penggunaan media tanam yang tepat dapat menentukan pertumbuhan bibit yang ditanam. Secara umum media tanam yang digunakan harus mempunyai sifat yang ringan, murah, mudah di dapat, gembur dan subur, sehingga memungkinkan pertumbuhan bibit yang optimum (Erlan,2005).

\section{Metodologi}

\section{Waktu dan Tempat}

Penelitian ini dilakukan pada bulan April - Juni 2018. Di Desa jingglong Kecamatan Sutojayan, Kabupaten Blitar (ketinggian tempat, suhu dan curah hujan) data Kabupaten Blitar

\section{Bahan dan Alat}

Bahan yang digunakan adalah bibit bawang merah varietas Thailand, air kelapa, pukan sapi, tanah, arang sekam, polybag 30x30, dan pupuk tambahan.Alat yang digunakan cangkil, ember, gembor, pisau, penggaris, timbangan analtik, kamera, alat tulis menulis.

\section{Metode Penelitian}

Penelitian ini menggunakan Rancangan Acak Kelompok (RAK). Dengan 9 kombinasi perlakuan yang di ulang 3x sehingga di hasilkan 27 satuan percobaan $\mathrm{K} 1=500 \mathrm{ml}$ air kelapa dalam $500 \mathrm{ml}$ air $(1 \mathrm{jam})$ $\mathrm{K} 2=500 \mathrm{ml}$ air kelapa dalam $500 \mathrm{ml}$ air $(2 \mathrm{jam})$ $\mathrm{K} 3=500 \mathrm{ml}$ air kelapa dalam $500 \mathrm{ml}$ air (3 jam) M1 = Tanah : Pukan Sapi : Abu Sekam(1:1:1) M2 = Tanah : Pukan Sapi : Abu Sekam(2:1:1) M3 = Tanah : Pukan Sapi : Abu Sekam (1:2:1)

Dari 9 perlakuan diulang 3 kali sehingga terdapat 27 satuan percobaan yang masing-masing percobaan terdiri dari 3 tanaman sehingga diperoleh jumlah seluruh tanaman yang dibutuhkan 81 tanaman perpolibag.

\section{Analisis Data}

Untuk menguji pengaruh perlakuan serta interaksinya, digunakan Uji F (Sidik Ragam). Bila hasil sidik ragam terhadap perlakuan berbeda tidak nyata (non signifikan) yang menunjukan $\mathrm{F}$ hitung $<\mathrm{F}$ tabel 0,05 maka tidak dilakukan uji lanjutan, tetapi bila hasil sidik ragam terhadap perlakuan berbeda nyata (signifikan) yang menunjukan $F$ hitung > F tabel 0.005 , maka untuk membandingkan dua rata-rata perlakuan dilakukan dengan uji. Beda Nyata Jujur (BNJ) dengan taraf kesalahan 5\%. 
Fendi Ramadhani, Tri Kurniastuti, Palupi Puspitorini 2019. Pengaruh Lama Perendaman Air Kelapa Terhadap Pertumbuhan dan Hasil Tanaman Bawang Merah (Allium ascalonicum. L) Pada Berbagai Macam Media Journal Viabel Pertanian. (2019), 13(1)33-44

\section{Variabel Pengamatan}

Variabel yang diamati pada penelitian ini meliputi komponen pertumbuhan (tinggi tanaman) dan komponen produksi (diameter buah, berat buah per tanaman).

\section{Hasil dan Pembahasan}

\section{Tinggi Tanaman}

Berdasarkan hasil analisis sidik ragam (ANOVA) pada taraf 5\% menunjukkan bahwa tidak terdapat interaksi yang nyata antara perlakuan lama perendaman air kelapa dan berbagai macam media terhadap tinggi tanaman bawang merah pada semua umur pengamatan. Perlakuan perendaman pada air kelapa $(\mathrm{K})$ memberikan pengaruh nyata terhadap tinggi tanaman bawang merah pada umur pengamatan 14hst dan 21 hst, (lampiran 2 dan 3). Dan pada perlakuan berbagai macam media (M) memberikan pengaruh nyata terhadap tinggi tanaman bawang merah pada umur $7 \mathrm{hst}, 14 \mathrm{hst}$, dan 21 hst (lampiran 1, 2, dan 3). Untuk mengetahui perlakuan mana yang terbaik dapat dilihat pada tabel 1 di bawah ini :

Tabel 1. Pengaruh Perendaman Pada Air Kelapa (K) dan Berbagai Macam Media (M) Terhadap Tinggi Tanaman Bawang Merah Pada Semua Umur Pengamatan.

\begin{tabular}{|l|l|l|l|l|l|}
\hline \multirow{3}{*}{ Perlakuan } & \multicolumn{5}{|c|}{ Tinggi Tanaman (cm) } \\
\cline { 2 - 6 } & 7 hst & 14 hst & 21 hst & 28 hst & 35 hst \\
\cline { 2 - 6 } & $11.51 \mathrm{a}$ & $23.75 \mathrm{~b}$ & $31.15 \mathrm{~b}$ & $35.23 \mathrm{a}$ & $35.44 \mathrm{a}$ \\
\hline K1 (1jam) & $11.52 \mathrm{a}$ & $22.42 \mathrm{a}$ & $29.05 \mathrm{a}$ & $34.06 \mathrm{a}$ & $35.38 \mathrm{a}$ \\
\hline K2 (2jam) & $11.25 \mathrm{a}$ & $21.81 \mathrm{a}$ & $28.38 \mathrm{a}$ & $32.75 \mathrm{a}$ & $34.43 \mathrm{a}$ \\
\hline & \multicolumn{5}{|c|}{ Media Tanam } \\
\hline M1 (1:1:1) & $10.61 \mathrm{a}$ & $21.36 \mathrm{a}$ & $28.81 \mathrm{a}$ & $34.47 \mathrm{a}$ & $36.20 \mathrm{a}$ \\
\hline M2 (2:1:1) & $12.11 \mathrm{~b}$ & $23.40 \mathrm{a}$ & $30.91 \mathrm{~b}$ & $34.11 \mathrm{a}$ & $34.63 \mathrm{a}$ \\
\hline M3 (1:2:1) & $11.56 \mathrm{ab}$ & $23.21 \mathrm{~b}$ & $28.86 \mathrm{a}$ & $33.44 \mathrm{a}$ & $34.43 \mathrm{a}$ \\
\hline
\end{tabular}

Keterangan : Angka-angka yang diikuti dengan huruf yang sama pada baris dan kolom yang sama tidak berbeda nyata pada uji Duncan $(\alpha=0,05)$.

Dari tabel 1 di atas, ditunjukkan pada umur 7 hst bahwa perendaman pada air kelapa $(\mathrm{K})$ tidak berbeda nyata terhadap tinggi tanaman, dengan nilai rata-rata berkisar antara $11.25 \mathrm{~cm}$ sampai $11.52 \mathrm{~cm}$. Pada pengamatan umur $14 \mathrm{hst}$ menunjukan perbedaam nyata pada perendaman air kelapa $(\mathrm{K})$ terhadap tinggi tanaman dengan nilai rata- rata tertinggi pada perendaman air kelapa selama 1 jam (K1) yaitu $23,75 \mathrm{~cm}$, sedangkan yang menunjukan nilai terendah pada perendaman air kelapa selama 3 jam (K3) yaitu $21,81 \mathrm{~cm}$ dan tidak berbeda dengan perlakuan perendaman selama 2 jam (K2). Pada pengamatan umur 21 hst menunjukan perbedaan yang nyata pada perendaman air kelapa (K) terhadap tinggi tanaman dengan nilai rata-rata tertinggi pada perendaman selama 1 jam (K1) yaitu $31.15 \mathrm{~cm}$, sedangkan yang menunjukan nilai terendah pada perendaman air kelapa selama 3 jam (K3) yaitu $28.38 \mathrm{~cm}$ dan tidak berbeda dengan perendaman selama 2 jam (K2). Pada pengamatan umur 28 hst perendaman air kelapa (K) tidak berbeda nyata terhadap 
tinggi tanaman, dengan nilai rata- rata berkisar antara $32.75 \mathrm{~cm}$ sampai $35.23 \mathrm{~cm}$. Pada pengamatan umur 35 hst perendaman air kelapa $(\mathrm{K})$ tidak berbeda nyata terhadap tinggi tanaman, dengan nilai rata- rata berkisar antara $34.43 \mathrm{~cm}$ sampai $35.75 \mathrm{~cm}$.

Dari tabel 1 di atas ditunjukkan pada umur 7 hst bahwa perlakuan pada berbagai macam media menunjukkan perbedaan nyata terhadap tinggi tanaman, nilai rata-rata tertinggi pada media tanah 2 : pupuk 1 : abu sekam 1 (M2) yaitu $12.11 \mathrm{~cm}$ sedangkan yang menunjukan nilai terendah pada media tanah 1: pupuk 1: abu sekam : (M1) yaitu $11,61 \mathrm{~cm}$. Pada pengamatan umur $14 \mathrm{hst}$ perlakuan pada berbagai macam media menunjukan berbeda nyata terhadap tinggi tanaman nilai rata-rata tertinggi pada media tanah 2 : pupuk 1 : abu sekam $1(\mathrm{M} 2)$ yaitu $23,40 \mathrm{~cm}$, sedangkan nilai rata-rata terendah pada media tanah 1 : pupuk 1 : abu sekam 1 (M1) yaitu 21,36 cm. Pengamatan umur 21 hst perlakuan pada berbagai macam media menunjukan berbeda nyata terhadap tinggi tanaman nilai rata-rata tertinggi pada media tanah 2 : pupuk $1:$ abu sekam 1 (M2) yaitu $30,91 \mathrm{~cm}$, sedangkan nilai rata-rata terendah pada media tanah 1 : pupuk $1:$ abu sekam 1 (M1) yaitu $28,81 \mathrm{~cm}$. Pada pengamatan umur $28 \mathrm{hst}$ perlakuan pada berbagai macam media menunjukan tidak berbeda nyata terhadap tinggi tanaman, dengan nilai rata-rata berkisar antara $33.44 \mathrm{~cm}$ sampai $34.47 \mathrm{~cm}$. Pada pengamatan umur 35 hst perlakuan pada berbagai macam media menunjukan tidak berbeda nyata terhadap tinggi tanaman, dengan nilai rata-rata berkisar antara $34.43 \mathrm{~cm}$ sampai $36.20 \mathrm{~cm}$.

Dari tabel di atas dapat disimpulkan bahwa dari berbagai macam media menunjukan perbedaan yang nyata pada umur $7 \mathrm{hst}, 14 \mathrm{hst}$ dan $21 \mathrm{hst}$, namun tidak berbeda nyata pada umur pengamatan lainya. Seperti pernyataan yang dikemukakan oleh Abidin (1987) auksin mempunyai kemampuan dalam perpanjangan sel tanaman, giberelin dapat menstimulasi pembelahan sel dan pemanjangan sel atau keduanya, sitokinin mendukung terjadinya pembelahan sel sehingga dapat meningkatkan pertumbuhan pada tanaman. Selain itu menurut pendapat Azwar (2008) bahwa air kelapa ternyata memiliki manfaat untuk meningkatkan pertumbuhan tanaman.(Salisburry dan Ross, 1995) mengemukakan bahwa, pemberian auksin dalam konsentrasi yang rendah akan memacu pemanjangan akar, Sedangkan pada konsentrasi yang lebih tinggi pemanjangan terhambat. Sejalan dengan pendapat (Watimena,1998) bahwa, dari berbagai percobaan yang telah dilakukan, IBA dan NAA merupakan zat pengatur tumbuh yang dapat menginduksi tumbuhnya akar pada stek tanaman berbatang lunak.

\section{Jumlah Tunas}

Berdasarkan hasil analisis sidik ragam (ANOVA) pada taraf 5\% menunjukkan bahwa tidak terdapat interaksi yang nyata antara perlakuan lama perendaman pada air kelapa (K) dan berbagai macam media (M) terhadap jumlah tunas tanaman bawang merah pada semua umur pengamatan. Perlakuan perendaman pada air kelapa (K) menunjukan perbedaan yang nyata pada semua umur pengamatan $7 \mathrm{hst}, 14 \mathrm{hst}, 21 \mathrm{hst}, 28$ hst, dan 35 hst .Sedangkan pada perlakuan berbagai macam media (M) tidak berbeda nyata pada semua umur pengamatan untuk mengetahui perlakuan mana yang terbaik dapat dilihat pada tabel di bawah ini 
Fendi Ramadhani, Tri Kurniastuti, Palupi Puspitorini 2019. Pengaruh Lama Perendaman Air Kelapa Terhadap Pertumbuhan dan Hasil Tanaman Bawang Merah (Allium ascalonicum. L) Pada Berbagai Macam Media Journal Viabel Pertanian. (2019), 13(1)33-44

Tabel 2. Pengaruh Perendaman Pada Air Kelapa (K) dan Berbagai Macam Media (M) Terhadap Jumlah Tunas Pada Tanaman Bawang Merah

\begin{tabular}{|l|l|l|l|l|l|}
\hline \multirow{2}{*}{ Perlakuan } & \multicolumn{5}{|c|}{ Bumlah Tunas (helai) } \\
\cline { 2 - 6 } & 7 hst & 14 hst & 21 hst & 28 hst & 35 hst \\
\cline { 2 - 6 } & $5.88 \mathrm{~b}$ & $7.07 \mathrm{~b}$ & $8.25 \mathrm{~b}$ & $12.10 \mathrm{~b}$ & $13.03 \mathrm{~b}$ \\
\hline K1 (1jam) & $4.07 \mathrm{a}$ & $4.70 \mathrm{a}$ & $6.25 \mathrm{a}$ & $8.81 \mathrm{a}$ & $9.36 \mathrm{a}$ \\
\hline K2 (2jam) & $4.44 \mathrm{a}$ & $4.75 \mathrm{a}$ & $6.51 \mathrm{a}$ & $8.88 \mathrm{a}$ & $9.36 \mathrm{ab}$ \\
\hline K3 (3jam) & \multicolumn{5}{|c|}{ Media Tanam } \\
\hline & $4.66 \mathrm{a}$ & $5.36 \mathrm{a}$ & $6.88 \mathrm{a}$ & $9.84 \mathrm{a}$ & $10.14 \mathrm{a}$ \\
\hline M1 (1:1:1) & $4.70 \mathrm{a}$ & $5.46 \mathrm{a}$ & $6.84 \mathrm{a}$ & $9.92 \mathrm{a}$ & $10.47 \mathrm{a}$ \\
\hline M2 (2:1:1) & $5.03 \mathrm{a}$ & $5.70 \mathrm{a}$ & $7.29 \mathrm{a}$ & $10.03 \mathrm{a}$ & $11.14 \mathrm{a}$ \\
\hline M3 (1:2:1) & & & \multicolumn{5}{|c|}{} \\
\hline
\end{tabular}

Keterangan : Angka-angka yang diikuti dengan huruf yang sama pada baris dan kolom yang sama tidak berbeda nyata pada uji Duncan $(\alpha=0,05)$.

Dari tabel 2 di atas di tunjukan pada umur 7 hst pada perlakuan perendaman pada air kelapa $(\mathrm{K})$ terdapat perbedaan nyata terhadap jumlah tunas tanaman bawang merah. Nilai rata-rata tertinggi pada perendaman air kelapa selama 1 jam (K1) yaitu 5.88, sedangkan nilai rata-rata terendah pada perendaman air kelapa selama 2 jam (K2) yaitu 4.07. Pada pengamatan umur 14 hst perendaman pada air kelapa $(\mathrm{K})$ berbeda nyata terhadap jumlah tunas tanaman bawang merah. Nilai rata-rata tertinggi pada perendaman air kelapa selama 1 jam (K1) yaitu 7.07, sedangkan nilai rata-rata terendah yaitu pada perendaman air kelapa selama 2 jam (K2) yaitu 4.70. Pada pengamatan $21 \mathrm{hst}$ perendaman pada air kelapa $(\mathrm{K})$ berbeda nyata terhadap jumlah tunas tanaman bawang merah. Nilai rata-rata tertinggi pada perendaman air kelapa selama 1 jam (K1) yaitu 8.25, sedangkan nilai rata-rata terendah yaitu pada perendaman air kelapa selama 2 jam (K2) yaitu 6.25. Pada pengamatan 28 hst perendaman pada air kelapa (K) berbeda nyata terhadap jumlah tunas tanaman bawang merah. Nilai rata-rata tertinggi pada perendaman air kelapa selama 1 jam (K1) yaitu 12.10, sedangkan nilai rata-rata terendah yaitu pada perendaman air kelapa selama 2 jam (K2) yaitu 8.81. Pada pengamatan 35 hst perendaman air kelapa $(\mathrm{K})$ berbeda nyata terhadap jumlah tunas tanaman bawang merah. Nilai rata-rata tertinggi pada perendaman air kelapa selama 1 jam (K1) yaitu 13.03, sedangkan nilai rata-rata terendah pada perendaman air kelapa selama 2 jam (K2) yaitu 9.36 .

Dari tabel 2 di atas ditunjukkan pada umur 7 hst perlakuan pada berbagai macam media (M) menunjukkan tidak berbeda nyata terhadap jumlah tunas tanaman bawang merah dengan rata-rata nilai berkisar antara 4.66 sampai 5.03. Pada pengamatan $14 \mathrm{hst}$ perlakuan pada berbagai macam media (M) menunjukan tidak berbeda nyata terhadap jumlah tunas tanaman bawang merah dengan nilai rata-rata berkisar antara 5.36 sampai 5.70. Pada pengamatan 21 hst bahwa perlakuan pada berbagai macam media (M) menunjukan tidak berbeda nyata terhadap jumlah tunas tanaman bawang merah dengan nilai rata-rata berkisar antara 6.84 sampai 7.29. Pada pengamatan 28 hst bahwa perlakuan pada berbagai macam media (M) menunjukan tidak berbeda nyata terhadap jumlah tunas tanaman bawang merah dengan nilai rata-rata berkisar antar 9.84 sampai 10.03. Pada pengamatan 35 hst bahwa perlakuan pada berbagai macam media (M) menunjukan tidak 
berbeda nyata terhadap jumlah tunas tanaman bawang merah dengan nilai rata-rata berkisar antara 10.14 sampai 11.14. Selain itu menurut (Marfirani, 2014) bahwa air kelapa juga mengandung zat pengatur tumbuh berupa hormone auksin dan gibberellin, sehingga memacu pertumbuhan. Menurut Suryo, (1995) hormone auksin akan meningkatkan pertumbuhan sampai mencapai konsentrasi yang optimal. Apabila konsentrasi yang diberikan melebihi konsentrasi yang optimal, maka akan mengganggu metabolisme dan perkembangan tumbuhan sehingga menurunkan pertumbuhan. Konsentrasi yang terlalu pekat dapat menghambat dan memperlambat pertumbuhan dan produksi tanaman.

\section{Jumlah Daun}

Berdasarkan analisis sidik ragam (ANOVA) pada taraf 5\% bahwa tidak terdapat interaksi yang nyata dari perlakuan perendaman air kelapa $(\mathrm{K})$ dan berbagai macam media terhadap jumlah daun tanaman bawang merah pada semua umur pengamatan.Namun pada perlakuan perendaman air kelapa $(\mathrm{K})$ terdapat terdapat perbedaan yang nyata terhadap jumlah daun tanaman bawang merah pada semua umur pengamatan.Pada perlakuan berbagai macam media (M) tidak terdapat perbedaan yang nyata pada semua umur pengamatan. Untuk mengetahui perlakuan mana yang terbaik dapat dilihat pada tabel di bawah ini :

Tabel 3. Pengaruh Perendaman Air Kelapa (K) dan Berbagai Macam Media Terhadap Jumlah Daun Tanaman Bawang Merah.

\begin{tabular}{|l|l|l|l|l|l|}
\hline \multirow{2}{*}{ Perlakuan } & \multicolumn{5}{|c|}{ Jumlah Daun (helai) } \\
\cline { 2 - 6 } & 7 hst & 14 hst & 21 hst & 28 hst & 35 hst \\
\cline { 2 - 6 } & $11.03 \mathrm{~b}$ & $17.70 \mathrm{~b}$ & $32.66 \mathrm{~b}$ & $36.66 \mathrm{~b}$ & $39.73 \mathrm{~b}$ \\
\hline K1 (1jam) & $8.07 \mathrm{a}$ & $13.32 \mathrm{a}$ & $23.77 \mathrm{a}$ & $26.44 \mathrm{a}$ & $29.07 \mathrm{a}$ \\
\hline K2 (2jam) & $8.29 \mathrm{a}$ & $12.55 \mathrm{a}$ & $23.36 \mathrm{a}$ & $26.66 \mathrm{a}$ & $29.29 \mathrm{a}$ \\
\hline K3 (3jam) & \multicolumn{5}{|c|}{ Media Tanam } \\
\hline & $9.55 \mathrm{a}$ & $14.66 \mathrm{a}$ & $26.10 \mathrm{a}$ & $29.77 \mathrm{a}$ & $32.73 \mathrm{a}$ \\
\hline M1 (1:1:1) & $8.18 \mathrm{a}$ & $13.81 \mathrm{a}$ & $26.47 \mathrm{a}$ & $30.14 \mathrm{a}$ & $32.07 \mathrm{a}$ \\
\hline M2 (2:1:1) & $9.66 \mathrm{a}$ & $15.10 \mathrm{a}$ & $27.21 \mathrm{a}$ & $29.85 \mathrm{a}$ & $33.81 \mathrm{a}$ \\
\hline M3 (1:2:1) & &
\end{tabular}

Keterangan : Angka-angka yang diikuti dengan huruf yang sama pada baris dan kolom yang sama tidak berbeda nyata pada uji Duncan $(\alpha=0,05)$.

Dari tabel 3 di atas di tunjukan pada umur 7 hst pada perlakuan perendaman pada air kelapa $(\mathrm{K})$ terjadi perbedaan nyata terhadap jumlah daun tanaman bawang merah. Nilai rata-rata tertinggi pada perendaman air kelapa selama 1 jam (K1) yaitu 11.03, sedangkan nilai rata-rata terendah pada perendaman air kelapa selama 2 jam (K2) yaitu 8.07. Pada pengamatan 14 hst perendaman pada air kelapa (K) berbeda nyata terhadap jumlah daun tanaman bawang merah. Nilai rata-rata tertinggi pada perendaman air kelapa selama1 jam (K1) yaitu 17.70, sedangkan nilai rata-rata terendah pada perendaman air kelapa selama 3 jam (K3) yaitu 12.55. Pada pengamatan 21 hst perendaman pada air kelapa $(\mathrm{K})$ berbeda nyata terhadap jumlah daun tanaman bawang merah. Nilai rata-rata 
tertinggi pada perendaman air kelapa selama 1 jam (K1) yaitu 32.66, sedangkan nilai ratarata terendah pada perendaman air kelapa selama 3 jam (K3) yaitu 23.36. Pada pengamatan 28 hst perendaman air kelapa $(\mathrm{K})$ berbeda nyata terhadap jumlah daun tanaman bawang merah. Nilai rata-rata tertinggi pada perendaman air kelapa selama 1 jam $(\mathrm{K})$ yaitu 36.66, sedangkan nilai rata-rata terendah pada perendaman air kelapa selama 2 jam (K2) yaitu 26.44. Pada pengamatan 35 hst perendaman air kelapa (K) berbeda nyata terhadap jumlah daun tanaman bawang merah. Nilai rata-rata tertinggi pada perendaman air kelapa selama 1 jam (K1) yaitu 39.73, sedangkan nilai rata-rata terendah pada perendaman air kelapa selama 2 jam (K2) yaitu 29.07.

Dari tabel 3 di atas ditunjukkan pada umur 7 hst perlakuan pada berbagai macam media (M) menunjukkan tidak berbeda nyata terhadap jumlah daun tanaman bawang merah dengan rata-rata nilai berkisar antara 8.18 sampai 9.66. Pada pengamatan 14 hst perlakuan pada berbagai macam media $(\mathrm{M})$ menunjukan tidak berbeda nyata terhadap jumlah daun tanaman bawang merah nilai rata-rata berkisar antara 13.81 sampai 15.10. Pada pengamatan 21 HST perlakuan pada berbagai macam media (M) menunjukan tidak berbeda nyata terhadap jumlah daun tanaman bawang merah nilai rata-rata berkisar antara 26.10 sampai 27.21. Pada pengamatan 28 hst perlakuan pada berbagai macam media (M) menunjukan tidak berbeda nyata terhadap jumlah daun tanaman bawang merah nilai ratarata berkisar antara 29.77 sampai 30.14. Pada pengamatan $35 \mathrm{hst}$ perlakuan pada berbagai macam media (M) menunjukan tidak berbeda nyata terhadap jumlah daun tanaman bawang merah nilai rata-rata berkisar antara 32.07 sampai 33.81 .

Pernyataan tersebut sesuai dengan pendapat yang dikemukakan oleh Salisbury (1995), yang menyatakan bahwa endosperm cair buah kelapa yang belum matang mengandung senyawa yang dapat memacu sitokinesis. Menurut Puspita (2011) penambahan air kelapa berperan penting dalam proses pembentukan dan pertumbuhan daun karena di dalam air kelapa terdapat hormone sitokinin yang mampu merangsang pembentukan daun dengan baik. Selain itu menurut Kusuma (2003) bahwa dalam pengaplikasian hormone perlu diperhatikan ketepatan dosis, karena jika dosis terlampau panjang bukan memacu pertumbuhan tanaman tetapi bisa menghambat pertumbuhan tanaman dan menyebabkan keracunan pada seluruh jaringan tanaman.

\section{Berat Brangkasan}

Berdasarkan hasil analisis sidik ragam (ANOVA) pada taraf 5\% menunjukkan bahwa tidak terdapat interaksi yang nyata antara perlakuan perendaman pada air kelapa (K) dan berbagai macam media (M) terhadap berat brangkas umbi tanaman bawang merah . Perlakuan perendaman pada air kelapa (K) tidak berpengaruh nyata terhadap berat brangkas tanaman bawang merah pada saat pemanenan .Pada perlakuan berbagai macam media (M) menunjukan pengaruh nyata terhadap berat brangkas tanaman bawang merah pada saat pemanenan. Untuk mengetahui perlakuan mana yang terbaik dapat dilihat pada tabel di bawah ini : 
Fendi Ramadhani, Tri Kurniastuti, Palupi Puspitorini 2019. Pengaruh Lama Perendaman Air Kelapa Terhadap Pertumbuhan dan Hasil Tanaman Bawang Merah (Allium ascalonicum. L) Pada Berbagai Macam Media Journal Viabel Pertanian. (2019), 13(1)33-44

Tabel 4.Pengaruh Perendaman Air Kelapa (K) dan Berbagai Macam Media Terhadap Berat Brangkas Tanaman Bawang merah.

\begin{tabular}{|c|c|}
\hline Perlakuan & Berat brangkas \\
\hline & Bahan Organik \\
\hline K1 (1 jam) & $108.52 \mathrm{a}$ \\
\hline K2 (2 jam) & 98.69 a \\
\hline \multirow[t]{2}{*}{ K3 (3 jam) } & 105.74 a \\
\hline & MEDIA \\
\hline M1 (1:1:1) & $122.03 \mathrm{~b}$ \\
\hline M2 (2:1:1) & $98.70 \quad \mathrm{a}$ \\
\hline M3 (1:2:1) & $92.21 \quad \mathrm{a}$ \\
\hline
\end{tabular}

Dari tabel 4 di atas bahwa perlakuan perendaman air kelapa tidak terjadi pengaruh yang nyata pada waktu pemanenan terhadap berat brangkasan tanaman bawang merah. Pada perlakuan perendaman air kelapa $(\mathrm{K})$ tidak menunjukan perbedaan yang nyata nilai rata-rata berkisar antara 98.69 sampai 108.52 .

Pada perlakuan berbagai macam media (M) menunjukan perbedaan yang nyata terhadap berat brangkasan umbi per tanaman bawang merah nilai rata-rata tertinggi pada perlakuan berbagai media tanah 1: pupuk 1 : abu sekam 1 (M1) yaitu $122.03 \mathrm{gr}$, sedangkan nilai rata-rata terendah pada perlakuan berbagai media tanah $1:$ pupuk $2:$ abu sekam 1 (M3) yaitu 92.21 gr. Sesuai dengan pendapat yang dikemukakan oleh Lingga dan Marsono (2001) bahwa pertumbuhan vegetative yang baik akan membantu terbentuknya karbohidrat untuk kebutuhan tanaman maupun produksi dimana adanya unsur hara yang cukup akan dapat diserap oleh akar yang akan diangkat kedaun untuk proses fotosintesa dan hasil fotosintat inilah yang akan disimpan ke umbi. Hammin (2004) menambahkan bahwa semakin banyaknya daun laju fotosintesa akan semakin meningkat dan hasil fotosintat yang ditumpuk ke umbi semakin banyak pula.

\section{Berat Basah}

Berdasarkan hasil analisis sidik ragam (ANOVA) pada taraf 5\% menunjukkan bahwa tidak terjadi interaksi yang nyata antara perlakuan perendaman air kelapa (K) dan berbagai macam media $(\mathrm{M})$ terhadap berat basah pada tanaman bawang merah.Perlakuan perendaman air kelapa $(\mathrm{K})$ tidak berpengaruh nyata terhadap berat basah tanaman bawang merah pada saat panen.

Namun perlakuan pada berbagai macam media $(\mathrm{M})$ menunjukan pengaruh nyata terhadap berat basah umbi per tanaman bawang merah pada waktu panen. Untuk mengetahui perlakuan mana yang terbaik dapat dilihat pada tabel di bawah ini : 
Fendi Ramadhani, Tri Kurniastuti, Palupi Puspitorini 2019. Pengaruh Lama Perendaman Air Kelapa Terhadap Pertumbuhan dan Hasil Tanaman Bawang Merah (Allium ascalonicum. L) Pada Berbagai Macam Media Journal Viabel Pertanian. (2019), 13(1)33-44

Tabel 5.Pengaruh Perendaman Air Kelapa (K) dan Berbagai Macam Media Terhadap Berat Basah Tanaman Bawang merah.

\begin{tabular}{ll}
\hline Perlakuan & Berat Basah \\
\hline & Bahan Organik \\
K1 (1 jam) & $78.11 \mathrm{a}$ \\
K2 $(2$ jam) & $70.36 \mathrm{a}$ \\
K3 (3 jam) & $67.03 \mathrm{a}$ \\
& Media Tanam \\
M1 (1:1:1) & $80.51 \mathrm{~b}$ \\
M2 (2:1:1) & $69.62 \mathrm{ab}$ \\
M3 (1:2:1) & $65.36 \mathrm{a}$ \\
\hline
\end{tabular}

Keterangan : Angka-angka yang diikuti dengan huruf yang sama pada baris dan kolom yang sama tidak berbeda nyata pada uji Duncan $(\alpha=0,05)$.

Dari tabel 5 di atas bahwa perlakuan perendaman air kelapa (K) tidak terjadi pengaruh yang nyata pada waktu panen terhadap berat basah tanaman bawang merah nilai rata-rata berkisar antara 67.03 sampai $78.11 \mathrm{gr}$.

Pada perlakuan berbagai macam media (M) menunjukan pengaruh yang nyata pada saat pemanenan. Nilai rata-rata tertinggi pada perlakuan berbagai macam media tanam tanah 1: pupuk 1 : abu sekam 1 (M1) yaitu $80.51 \mathrm{gr}$, sedangkan nilai rata-rata terendah pada perlakuan berbagai macam media tanah 1 : pupuk 2 : abu sekam 1 (M3) yaitu 65.36 gr. Menurut Syekhfani (2000), pupuk kandang memiliki sifat yang alami dan tidak merusak tanah, menyediakan unsur hara makro (Nitrogen, Fosfor, Kalium, Kalsium, dan Belerang) dan mikro (Besi, Boron, Seng, Kobalt dan Molibdenum). Selain itu pupuk kandang berfungsi untuk meningkatkan daya tahan menahan air, aktifitas mikrobiologi tanah, nilai kapasitas tukar kation dan dapat memperbaiki struktur tanah.Selain itu menurut Setiawan (2000), pengaruh pemberian pupuk kandang secara tidak langsung adalah memudahkan tanah untuk menyerap air.

Menurut Febrynugroho (2009) bahwa abu sekam padi berfungsi mengikat logam berat dan menggemburkan tanah sehingga mempermudah akar tanaman menyerap unsur hara di dalamnya.Sejalan dengan Nurita dan Jumberi (1997) menyatakan bahwa abu sekam padi sebagai penyedia $\mathrm{Ca}, \mathrm{Mg}, \mathrm{K}$ dan $\mathrm{P}$ dapat menaikkankan $\mathrm{pH}$ tanah serta meningkatkan hasil tanaman.

\section{Kesimpulan}

Berdasarkan hasil penelitian mengenai Perendaman pada air kelapa dan Berbagai Macam Media Terhadap Pertumbuhan dan Hasil Tanaman Bawang Merah dapat disimpulkan sebagai berikut :

1. Dari perlakuan lama waktu perendaman dan berbagai macam media tidak menunjukan interaksi yang nyata terhadap pertumbuhan dan hasil tanaman bawang merah.

2. Perlakuan yang terbaik adalah perendaman selama 1 jam (K1) dengan hasil jumlah tunas $28 \%$ lebih baik di banding dengan perlakuan lain.

3. Pada perlakuanberbagai macam media perlakuan terbaik adalah (M1) dengan hasil18,8\%lebih baik disbanding dengan(M3). 


\section{Saran}

Dari penelitian ini penulis menyarankan perendaman benih bawang merah selama 1 jam untuk mendapatkan pertumbuhan vegetative yang baik. Dan penulis menyarankan media yang digunakan untuk menanam bawang merah harus bersifat remah, ringan dan mudah didapat.Karena dengan media tersebut tanaman bawang merah dapat menghasilkan umbi yang banyak dan maksimal.

\section{Daftar Pustaka}

Abidin, Z. 1985.Dasar-dasar Pengetahuan tentang Zat Pengatur Tumbuh. Penerbit Angkasa, Bandung.

Abdurrahman, A., I. Juarsah, U. Kurnia. 1999. Pengaruh penggunaan berbagai jenis dan takaran pupuk kandang terhadap produktivitas tanah Ultisol terdegradasi di Desa Batin, Jambi. Prosiding. Seminar Nasional Sumberdaya Tanah, Iklim dan Pupuk. Pusat Penelitian Tanah dan Agroklimat.Badan Penelitian dan Pengembangan Pertanian. Departemen Pertanian. Jakarta.

Anwar, S. 2008. "Ampas Tebu”. Catatan Ringan Nur Hidayat. http://bioindustri.blogspot.com /2008/04/ampas-tebu.html. [diakses 08 Nopember 2013]

Agoes, S.D., 1994. Aneka Jenis Media Tanam dan Penggunaannya.Penebar.Swadaya. Jakarta

Dwidjoseputro.D. 1989.Pengantar Fisiologo Tumbuhan.Jakarta:Gramedia.

Erlan. 2005. Pengaruh Berbagai Media Terhadap Pertumbuhan Bibit Mahkota Dewa (Phaleria macrocarpha (Scheff.) Boerl.)di Polibeg. Jurnal Akta Agrosia, $7:$ 72-75

Febrynugroho. 2009. Manfaat Abu Sekam Padi. http://febrynugroho.wordpress.com/2009/04/03/manfaatabu-sekam-padi/. Diakses 11 September 2016.

Hadisumitro, L. M. 2002. Membuat Kompos. Jakarta: Penebar Swadaya, 54 hal.

Hammin. 2004. Underlaying drought stress effect on plant : inhibition of photosynthesis Jurnal of Biosciens

Harjadi, S. S. 2009. Zat Pengatur Tumbuhan. Jakarta: Penebar Swadaya.

Hendaryono, D. P. S dan Wijayani. 1994. Teknik Kultur Jaringan dan Petunjuk Perbanyakan Tanaman Secara Vegetatif Modern. Yogyakarta: Kanisius.

Junaidi, I., Sartono. J. S., Endang. S. S. 2013.Pengaruh Macam Mulsa dan Pemangkasan Terhadap Pertumbuhan dan Hasil Tanaman Semangka (Citrullus vulgarisschard).UNISRI, Surakarta.Jurnal Inovasi Penelitian.

Kristina, N. N., dan Syahid, S. F. 2012. Pengaruh Air Kelapa terhadap Muliplikasi Tunas In Vitro, Produksi Rimpang, dan Kandungan Xanthorizol Temulawak di Lapangan.Jurnal Littri, 18 (3): 125 - 134. 
Fendi Ramadhani, Tri Kurniastuti, Palupi Puspitorini 2019. Pengaruh Lama Perendaman Air Kelapa Terhadap Pertumbuhan dan Hasil Tanaman Bawang Merah (Allium ascalonicum. L) Pada Berbagai Macam Media Journal Viabel Pertanian. (2019), 13(1)33-44

Kusuma, A S,. 2003.Pengaruh Zat Pengatur Tumbuh Rootone-F Terhadap Keberhasilan Setek Manglid.Institut Pertanian Bogor.Bogor.

Lawalata, Imelda J. 2011. Pemberian Beberapa Kombinasi ZPT terhadap Regerasi Tanaman Gloxinia dari Eksplan Batang dan Daun Secara In-Vitro.Jurnal Hayati 1 (2). Bogor: Lembaga Ilmu Pengetahuan Indonesa. p: 83-87.

Marfirani, M. 2014. Pengaruh Pemberian Berbagai Konsentrasi Filtrat Umbi Bawang Merah dan Rootone-F Terhadap Pertumbuhan Stek Melati" Rato Ebu'.Lentera Bio $3(1): 73-76$.

Musnamar. 2003. Pupuk Organik: Cair \& Padat, Pembuatan, Aplikasi. Penebar Swadaya. Jakarta.

Mayun, I. A. 2007. Efek Mulsa Jerami dan Pupuk Kandang Sapi Terhadap Pertumbuhan Dan Hasil Bawang Merah Di Daerah Pesisir. Jurusan Budidaya Pertanian Universitas Udayana.

Mukarlina, Listiawati, A. \& Mulyani, S. (2010) The Effect of Coconut Water and Naphthalene Acetic Acid (NAA) Application on the In Vitro Growth of Paraphalaeonopsis serpentilingua from West Kalimantan.Nusantara Bioscience. 2 (2), 62-66.doi:10.13057/nusbiosci/n020202.

Muslihat, L. 2003. Ekologi Gambut. Wetlands Internasional Indonesia Programme. Bogor. 25 Maret 2011.

Marsono dan P. Sigit 2001.Pupuk Kandang dan Aplikasi Pupuk Akar. Penebar Swadaya. Jakarta. $96 \mathrm{hlm}$.

Nurita dan A. Jumberi. 1997. Pemupukan KcL dan abu serbuk gergaji pada padi gogo di tanah podsolik merah kuning dalam prosiding seminar pembangunan pertanian berkelanjutan menyongsong era globalisasi (Buku 1).Peragi Komisariat Kalimantan Selatan.Banjarbaru.

Pamungkas T. Febriani., S. Darmanti dan B. Raharjo. 2009. Pengaruh Pemberian Air Kelapa Terhadap Pertumbuhan Tanaman Anggrek dan Kantong Semar (Paphioledilum supardi braem dan loeb) Pada Media Khudson secara in vitro. Mulawarna Scientifi. Vol. 10, No. 2 1412-498.

Pitojo, S 2003, 'Benih bawang merah. Seri Penangkaran', Penerbit Kanisius.

Prihatmani, D dan N. A. Mattjik, 2004.Penggunaan Zat Pengatur Tumbuh NAA (Naphtalene Acetic Acid) dan BAP (6-BenzilAmino Purine) serta Air Kelapa untuk Menginduksi Organogenesis Tanaman Anthurium (Anthuriumandraeanum Linden ex Andre).Bul. Agron. 32(1): 20-25.)

Poerwanto.2003. Pengelolaan Tanah dan Pemupukan Kebun Buah-Buahan. Bahan Ajar Budidaya Buah-Buahan Modul VII . Bogor. Institut Pertanian Bogor. $41 \mathrm{Hal}$

Pranata, A.S. 2010.Pupuk Organik Cair Aplikasi dan Manfaatnya.Agromedia Pustaka, Jakarta.

Rajiman.2014. Potensi Air Kelapa Bagi Pertanian.www.stppyogyakarta.ac.id/wpcontent/uploads/2014/12Potensi-air-kelapa-des.pdf.Diakses pada 20 Maret 2015. 
Salisburry, F.B. dan C.W. Ross. 1995. Fisiologi Tumbuhan.Terjemahan dari Plant Physiology oleh D.R. Lukman dan Sumaryono.ITB. Bandung. 133-139 hlm.

Salisbury, F.B. dan C.W. Ross. 1995. Fisiologi Tumbuhan, Biokimia Tumbuhan, jilid 2. Penerjemah: Lukman, D.R. dan Sumaryono. Bandung: Penerbit ITB.

Suriani, N. 2012.Bawang Bawa Untung. Budidaya Bawang Merah dan Bawang Merah.Yogyakarta: Cahaya Atma Pustaka.

Septiani, Dewi. 2012. Pengaruh Pemberian Arang Sekam Padi Terhadap Pertumbuhan Dan Hasil Tanaman Cabai Rawit (Capsicum frutescens). Skripsi.Lampung : Politeknik.

Setiawan, A.I. 2002. Manfaat Kotoran Ternak. Cetak Ke Tiga Penebar Swadaya. Jakarta.

Syekhfani. 2000.Arti penting bahan organic bagi kesuburan tanah. Jurnal Penelitian Pupuk Organik.

Sutedjo, M. M. 2010. Pupuk dan Cara Pemupukan. Rineka Cipta. Jakarta

Sutedjo, M. M. dan Kartasapoetra. 1990. Bertanam Jagung. Penebar Swadaya. Jakarta. $59 \mathrm{hlm}$.

Sunarjono, H. 2003. Bertanam 30 jenis sayuran. Penebar Swadaya, Jakarta.

Suryanto, E. 2009.Air Kelapa Dalam Media Kultur Pembibitan anggrek.Diakses dari http://www.wawaorchid.com pada tanggal 21 February 2016.

Suryo, 1995.Sitogenetika. Gadjah Mada University Press, Yogyakarta.

Tarigan, E, Yaya, H, dan Mariati. 2015. Respons pertumbuhan dan produksi bawang merah (Allium ascalonicum l.) terhadap pemberian abu vulkanik gunung sinabung dan arang sekam padi. Jurnal Online Agroekoteknologi.3(3): 956-962.

Tuhuteru, S., M.L. Hehanusa, S.H.T. Raharjo, 2012.Pertumbuhan dan Perkembangan Anggrek (Dendrobium anosmum) Pada Media Kultur In Vitro dengan Beberapa Konsentrasi Air Kelapa.www.ejournal.unpatti.ac.idDiases pada 20 Maret 2015.

Widyanto. 2007. Petunjuk Pemupukan. Agromedia Pustaka. Jakarta. (Online)

Wibowo, S., 2008, Budidaya Bawang, Bawang Merah, Bawang Putih, Bawang Bombay, Penebar Swadaya, Jakarta

Winarno, F. G. Dan M. A. Wirakartakusumah. (1981). Fisiologi Pasca Panen. Sastra Hudaya. Jakarta. $75 \mathrm{hlm}$.

Wuryaningsih, S. dan Darliah. 1994. Pengaruh Media Sekam Padi Terhadap Pertumbuhan Tanaman Hias Pot Spathiphyllum (Effect Of Rice Husk Media On Growth Of Spathiphyllum). Buletin Penelitian Tanaman Hias 2(2): 119-129 .

Yati Supriati dan Ersi Herliana.Bertanam 15 Sayuran Organik dalam Pot. Penebar Swadaya. Jakarta. 20

Young, J, W,II. Ge, L. Ng, Y, n Tan, N.2009. The Chemical Composition and Biological Properties of Coconut (Cooos nucifora L.) Whater.Natural Sciences and Sciences Education Group Nanyang Tehnological University. Singapore. 